Article

\title{
Role of Responsible leadership for Organizational Citizenship Behavior for the Environment in light of Psychological Ownership and Employee Environmental Commitment: A Moderated Mediation Model
}

\author{
Ali Abbas ${ }^{1}$, Bilal $^{*}$, Chengang Ye ${ }^{1}$, Shahid Manzoor ${ }^{3}$, Irfan Ullah ${ }^{4}$, Hafiz Muhammad Arslan ${ }^{4}$ \\ Business School, University of International Business and Economics, Beijing 100029, China. \\ School of Accounting, Hubei University of Economics, Wuhan 430205, China. \\ Hailey College of Commerce, University of the Punjab, Lahore 54000, Pakistan. \\ School of Management and Economics, Beijing Institute of Technology, Beijing 100081, China \\ * Correspondence: bilal@hbue.edu.cn (B.) \\ mianali348@hotmail.com (Ali Abbas), yechengang@uibe.edu.cn (Prof. Chengang Ye), \\ shahidmanzoor09@yahoo.com (Shahid Manzoor), irfanullahkhan9214@gmail.com (Irfan Ullah), \\ arslan@bit.edu.cn (Hafiz Muhammad Arslan).
}

\begin{abstract}
The world is looking towards organizations for social responsibility to contribute to a sustainable environment. Employees' organizational citizenship behavior for the environment (OCBE) is a voluntary environmental-oriented behavior that is important for organizations' environmental performance. Based on social learning theory, the study examined the effects of responsible leadership in connection with OCBE by using a sample of 520 employees of manufacturing and service sector including engine manufacturing, petroleum plants banking and insurance sector organizations of China. Further, the role of psychological ownership and employee environmental commitment were used as mediators and moderators simultaneously. The direct, mediation, and moderation model results exposed a positive relationship between responsible leadership and OCBE via employee psychological ownership and employee environmental commitment. The study also revealed that the indirect effect is stronger when employees hold higher employee environmental commitment. The theoretical and practical implications for environmental sustainability in respect of organizations as well as future research directions are discussed.
\end{abstract}

Keywords: Responsible leadership; Psychological ownership; Employee environmental commitment; Organizational citizenship behavior for the environment; China.

\section{Introduction}

Global climate change and biodiversity reduction are highly magnified in recent years that have raised positive ecological expectation from the corporate sector [1]. Enterprises are using green business activities, for example, green human resource management, green supply chain management, green finance are green strategic initiatives, to pursue long-term development [1]. The role of various stakeholders for sustainable development is crucial at all levels of organizations, including public, non-profit, and commercial entities. Environmental and sustainable managements' contribution has fascinated the management academics and policymakers [2]. Nonetheless, the management scholars paid attention to strategic and operational corporate environmental protection behavior but overlooked the vital role of employees' behavior towards sustainability and environmental protection [ $\underline{3}]$. 
Being critical stakeholders of organizations, organisations' environmental protection behaviour is highly dependent upon behaviors and interpersonal interaction of employees of any enterprise [ $\underline{4}$ ]. It is why the study of the behavior of employees directed toward the environment, known as organizational citizenship behavior for the environment (OCBE), is of significant prominence. Organizational citizenship behavior for the environment is a set of voluntary environmental-oriented activities and practices of employees within the organization that is not covered under any formal reward system [5]. Explicitly, individual employees engross environmental friendly behavior and formulate environmental friendly concepts consistent with green organizational strategy, for example, saving papers, reduced energy consumption, making recommendations, and helping colleagues engaging in environmental protective behaviors [6]. The substantial impact of employee environmental protective behavior and outcomes has driven the attention of factors encouraging OCBE. These factors include the self-responsibility of employees for environmental protection [ $\underline{7}$, corporate environmental concerns []], approaches, and attitudes [9]. In term of leadership behavior, recent studies have carried out endeavor and confirmed the role of ethical leadership [ $[\underline{7} \underline{10}]$, leaders support for the protection of the environment [11], are important contributor for OCBE.

OCBE is extra-role activities beyond the assigned job duties to improve and protect the organization's environmental performance [1]. Leadership affects organizational citizenship behavior for the environment in the shades of interaction between leaders and employees within an organization [10]. This is why arguing the impact of leaders on employees' environmental behaviour; the role of all the stakeholders cannot be neglected. Responsible leadership, a combination of leadership and social responsibility, is a leadership style that concentrates upon various stakeholders' interest, including employees, and struggles to incorporate social, economic, and environmental benefits [1]. It is aligning with the basic idea of OCBE. Several studies have explored the impact of leadership on OCBE [12], but a few studies examined the connection between responsible leadership and OCBE $[\underline{1}, \underline{10}, \underline{13}, \underline{14}]$. Responsible leadership takes environmental concerns as a critical stakeholder that corresponds with OCBE.

This paper significantly contributed to the existing literature on responsible leadership and organizational citizenship behavior for the environment in several ways. First, the rarely investigated phenomenon of responsible leadership in the eve of OCBE is investigated and extended. Responsible leadership undertakes the interest of stakeholders, including employees and their concerns about the environment and their psychological ownership for organizations. In this way, it further enriches the antecedents of OCBE. Second, this study also spades the existing model of responsible leadership and OCBE in light of employees' psychological ownership and analyzes its mediating effects on the primary relationship of OCBE and responsible leadership. Previously leadership role was highlighted with OCBE in the mediation of psychological ownership $[\underline{15}, \underline{16}]$, but the role of responsible leadership was not examined. Third, employee environmental commitment [17] was examined with other leadership, i.e. environmentally specific charismatic leadership [1] but not with responsible leadership and OCBE. To fill this gap, responsible leadership and psychological ownership are further tested with the moderating role of employee environmental commitment and adds to the existing body of knowledge. Fourth, previously much of OCBE research is carried out in the western context. However, this study is carried out in China's context, a country having many environmental concerns. The rest of the paper is distributed as follows; the subsequent section consists of literature review and hypothesis development. In the next section, the methodology of the paper is presented, and, is followed by the results and critical findings of study. Further discussion is carried out, and in the end, practical implications, limitations and suggestions are covered.

\section{Theory and Hypothesis Development}

\subsection{Responsible Leadership}


Responsible leadership originated from social relations and ethical theories and a leadership style that took place in the social interaction process [19]. Current globalized and economic scenarios, organizational networks, and diversified workforce have put challenges on leaders. Leaders not only pay attention to increasing profits for shareholders but also endeavor to fulfil the needs of stakeholders [20]. Multifarious stakeholder demands, compelling contests, and complex relation networks challenge the responsible leader to play a variety of roles in organizations [19]. A responsible leader could be a housekeeper, a dreamer, a democratic negotiator, motivator, decisionmaker, and discourser [21]. Responsible leaders always build and withstand profound relations among all the stakeholders by using the powerful forces of protection, acquisition, connection, and understanding [22].

Responsible leadership is a more complex and diverse leadership style than other traditional forms of leadership. The critical difference between other forms of leadership and responsible leadership is scope, values, society, and environment, and positive change [르] . Outmoded leadership styles exaggerate their influences but ignore the surrounding environment and overlook the interest of stakeholders. Other leadership styles also overlook the dimension of responsibility that is a crucial aspect of responsible leadership behavior [24]. On the other hand, responsible leadership style stresses for complex stakeholder-leader relationships. A responsible leader takes care of the needs of various stakeholders besides protecting the interest of shareholders.

\subsection{Responsible Leadership and Organizational Citizenship Behavior for the Environment}

Daily introduced the concept of Organizational Citizenship Behavior for the Environment (OCBE) in 2009; since then, it is popular among management scholars. It is a persons' voluntary behavior toward the environment in the organization which is not covered by any formal incentive system [ [ $]$ ]. The voluntary behavior of OCBE includes reduced consumption of energy and resources, less carbon footprinting, less usage of papers to save trees, helping colleagues, and proposing work suggestions in environment-friendly ways [25]. They further added that OCBE behavior works in three extents, i.e., eco-initiatives, eco-helping, and eco-civic engagements. Eco-initiatives are selfinitiative and trivial steps that the individual takes to upkeep the environmental activities. Ecohelping is such a work setting in which colleagues help each other in such activities that are proenvironmental. Moreover, Eco-civic engagements are green activities in the workplace. These include such steps and actions that contribute to the environment. OCBE fills the environmental gaps that are not identified and fixed by a formal system, by promoting the complementarity and collaboration with ceremonial environmental management systems that cut the organizational costs that occur on the environment and enrich the organizational reputation in term of environmental concerns [ $\underline{26}, \underline{27}]$ by engaging activities at individual level i.e. participation ability of employees' [26] or engaging organizational-level activities i.e. pro-environmental atmosphere [료] and organizational supervision [르].

Employees' initiatives for improvements in organizational environmental performances are widely studied and incorporated in green literature [25]. Employees' actions directed toward environmental improvement are critically important [5]. De Groot and Steg [30] claimed that environmental-oriented actions addresses environmental issues and help the growth of an organization. The connection between OCBE and responsible leadership is better govern by the social learning theory. According to social learning theory, individuals shape their behaviors by observing and reproducing the behaviors of others [31]. Responsible leaders pay attention to the interests of different stakeholders of the business, including employees. When employees and followers observe the behavior of the leader, they gradually accept and reproduce this behavior. Responsible leaders take consideration of ethical issues and strive hard for up keeping relationships with stakeholders. OCBE is an individual's ethical beliefs and actions that one takes to save the environment for oneself and society. This is why employees are inspired by responsible leaders, copy their environmentalfriendly actions, and engage in OCBE. 
Also, Stahl and Sully de Luque [32], claimed that a responsible leader encourages and reassures that organizations develop behavioral codes and measures that are related to the protection of the environment and clarifies environmentally friendly behaviors. Responsible leaders encourage employees for extra-role behaviors, as he takes care of the interest of all the stakeholders within or outside the organizations, employees notice it, imitate the behavior of caring others, and perform extra-role activities that are primarily directed towards the environment. Responsible leaders conglomerate social responsibility with economic, social, and ecological benefits of all the stakeholders, including employees of the organizations that inspire them. Voegtlin, et al. [21] call this role model effect through which a responsible leader can motivate employees effectively to take the initiative for OCBE. Based on this relationship, we hypothesize:

$\mathrm{H}_{1}:$ Responsible Leadership is positively associated with OCBE.

\subsection{Mediating Role of Psychological Ownership}

Psychological ownership is based upon psychological ownership theory and is defined by [33] as "the state in which individuals feel as though the target of ownership or a piece of that target is "theirs" (i.e., "It is mine!")". This is a state of mind in of employee that assumes the organization belongs to him. Pierce and colleagues, [33], claimed that psychological ownership depends upon three basic human needs, i.e., need of home or shelter, self-identity, and self-efficacy. The satisfaction of these basic instincts gives birth to a sense of psychological ownership. Based upon the work of [3335] conceptualized the four categories of psychological ownership are self-identity, self-efficacy, belongingness, and accountability. The sense of psychological ownership towards organization make employees more proactive and caring, attached to the organization with the sagacity of responsibility [36]. Responsible Leadership style based upon stakeholder relations and ethical consideration. This leadership style takes account of various stakeholder-leader relationships. This relationship is better to govern by the social exchange theory. According to Han, et al. [10] emotional resources are exchanges in human societies. A responsible leader takes care of the financial, social, psychological, and environmental needs of various stakeholders, including employees, besides protecting the interest of shareholders. This sense of care and protection by the leader positively impact employees as they feel an obliged and vital chunk of the institution. So in return for this emotional exchange, employees establish feelings of ownership for the institution, and they voluntarily invest extra time and energy for the organization and collective welfare. It is also evident from the previous literature that responsible leadership behavior is considered a critical factor that has a positive association with psychological ownership of employees [ $\underline{26}, \underline{37}, \underline{38}]$. A responsible leader takes care of the interests of employees and encourages them for their contribution to the process of decision making. It generates a sense of responsibility and accountability among followers. When employees are engaged in the decision-making process, they feel accomplished, show more considerable attention, put extra efforts to complete tasks and obtain targets and feel more responsible for the performance, and a sense of psychological ownership. Based on this relationship, we hypothesize:

\section{$\mathrm{H}_{2}$ : Responsible Leadership is significantly associated with psychological ownership.}

The study of O'driscoll, et al. [39] also clarified that employees' sense of ownership is affirmatively associated with organizational citizenship behavior and arouse employees for extrarole behaviors. Understanding employees that the organization is "theirs" (psychological ownership) gives birth to the feelings of a part and owner of the organization, bearing in mind full responsibility of the organization and striving hard for its sustainability. This pro-organizational affection and motivation make employees perform extra-role activities for the sustainability of the organization. OCBE is the voluntary actions of employees that are not governed by any formal reward system and directed toward environmental safety and sustainability. De Groot and Steg [30] claimed that environmental-oriented actions address environmental issues and further help for the organisation's 
growth by saving water, reduced usage of papers, less consumption of electricity, and green practices and procedures. The four dimension conceptualization of psychological ownership emphasized by [34] includes self-identity, self-efficacy, belongingness, and accountability. This is why, if employees assume the organization as "theirs" they consider the organization a significant part of theirs. The sense of belongingness and ownership, and they feel responsible and accountable for the organisation's sustainability. Psychologically owned employees think that if their organization is sustainable and prosperous, they are successful [40]. This ownership will breed extra motivation for doing the job, indulging voluntarily in extra-role activities that are beneficial for employees themselves, organization, and society i.e. OCBE. Thus, employees with psychological ownership for the organization in mind will take care of the organizational sustainability and take initiatives directed toward organizational behavior directed toward the environment for the organisation's support, i.e. OCBE.

$\mathrm{H}_{3}$ : Psychological ownership is significantly correlated with OCBE.

Responsible leadership style emphasizes upon stakeholder-leader approach. The responsible leader considers all the needs and demands of the stakeholders. All the social, psychological, financial, and environmental needs of various stakeholders are prioritized along with safeguarding shareholders and employees' interest. This care and sense of protection ignite positivity and a sense of importance among employees. They consider themselves an essential part of an organization and, in return, establish a sense of psychological ownership for the organization. They consider themselves responsible for organizational success and sustainability and voluntarily invest extra time and energy to discharge the responsibility of psychological ownership [ $\underline{34}, \underline{37}, \underline{38}]$. The employees' sense of accountability and psychological ownership motivate employees for the success and sustainability of organizations. Employees perform extra tasks other than their job description, complete extra-role activities, and indulge in such activities i.e. saving electricity, saving papers making green work environments [이. Psychological ownership will raise motivation for job performance and extra-role activities that are good for employees themselves, organization, and society i.e. OCBE. Thus, employees with psychological ownership for an organization in mind will take care of the sustainability of an organization will take more initiatives that will direct toward organizational citizenship behavior for an environment for the organisation's support. This discussion develops the hypothesis that:

$\mathrm{H}_{4}$ : Psychological ownership mediates the relationship between responsible Leadership and OCBE.

\subsection{Moderating Role of Employee Environmental Commitment}

Commitments have gained exceptional attention of management researchers as these are the gear of specific behavior to facilitate employees in the attainment of goals [ $[\underline{1}, \underline{42}]$, and great amount of research related to workplace commitments took place in the domain of organizational behavior [르]. In the literature of corporate greening, the role of commitment is widely studied as well [ㄴ4-46]. Commitment is an intuitively expressed mindset that provides behavioral directions towards any individual, idea, cause, or entity. Commitment toward a social or natural target, for example, the environment, is developed based upon normative and affective grounds[ $\underline{47} \underline{48}]$.

Employee environmental commitment is employee attachment and responsibility towards the environment at work [9ㅜ]. Daily and Huang [50] claimed in their study in (2001) that employee commitment towards an environment that motivates incessantly to be involved in behavior at the workplace that is environment friendly. This is why employees who are environmentally committed take environmental initiatives and extra perform than their assigned duties. Morgan and Hunt [51] also contributed that committed employees showed fewer intentions to leave and are more engaged with the organization, express more ownership, and exercise motivation. The environmentally committed employees perform extra-role behaviors, as they are more attached to the green mission 
of the organization and care about the environmental concerns of stakeholders [드]. Similarly, other studies also found that commitment has an interconnection between particular behaviors that target environment, ownership, and organization [ $[\underline{53}, \underline{54}]$.

Environmentally committed employees respond positively to signal from their organization regarding the environment and green practices [44]. The role of management is vital in the delivery of this signal. Managers who have strong knowledge of environmental issues and have control and decision-making powers are more practical to convince employees about environmental concerns [ [55]. Raineri and Paillé [49] conveyed that sense of employee environmental commitment develops in employees who see their leader's commitment with positivity and support his proenvironmental objectives.

The attitude theory Bagozzi [56] narrates that when employees' are appreciated and valued either by the leaders or management and organization, they express positive tendencies and affirmative response in return. A responsible leader cares about the interest of stakeholders, including employees and organization, as well as gives priorities to environmental concerns. When they are appreciated and valued by the responsible leaders, the employees who are environmentally committed are considered an essential part of the organization. The environmental concern of responsible leaders inspires and aligns employees' goals with the goals and objectives of their own, which are the objectives and mission of any organization. In this way, they increase their commitment and sense of psychological ownership for their organization. This discussion develops the next hypotheses that:

$\mathrm{H}_{5}$ : Employee environmental commitment moderates the relationship between responsible leadership and psychological ownership such that the relationship will be stronger for those high in Employee environmental commitment.

H6: Employee environmental commitment moderates the relationship between responsible leadership and OCBE such that the relationship will be stronger for those high in Employee environmental commitment.

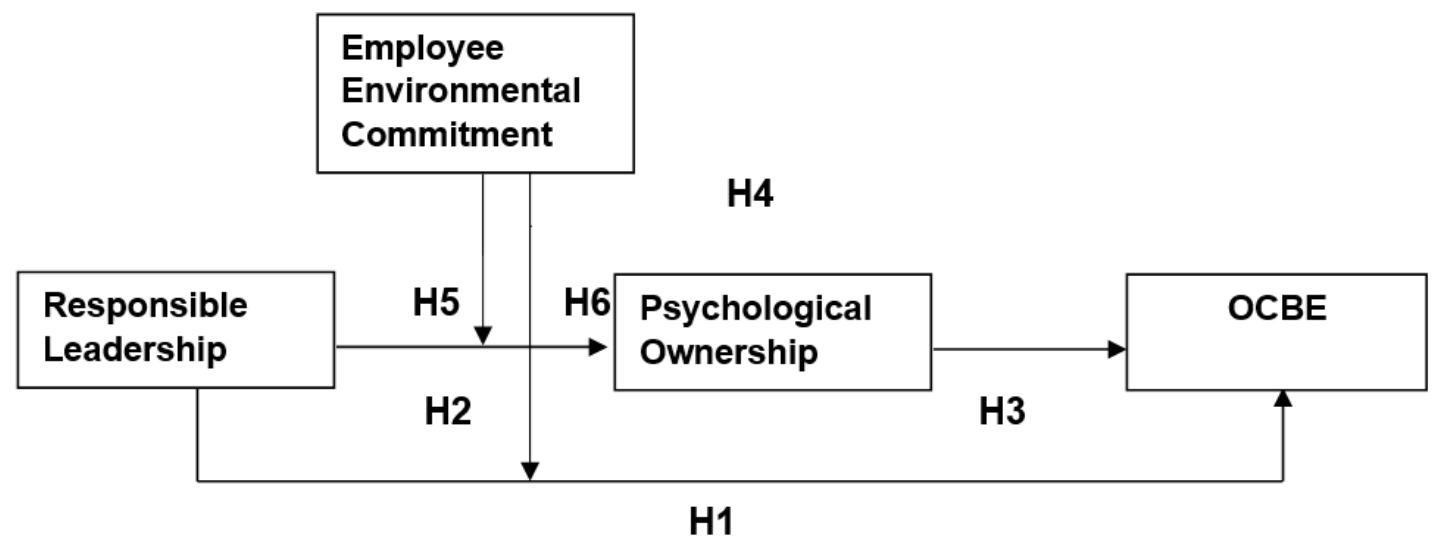

Figure 1. Model of this Study 


\subsection{Sample and Procedures}

The sample of the study includes 520 employees of six manufacturing and service organizations: an engine manufacturing plant, an insurance company, two petroleum manufacturing plants, and two banking offices located in Beijing, Sichuan, and Shaanxi provinces of China. Our respondents were Chinese. For this purpose, the English version of the survey was translated into the Chinese language by two Chinese professors with fluency in English and Chinese languages. For the accuracy of the Chinese version of the survey, it was again translated back into English by similar Chinese professors [ㅁ]].

The firms' human resource departments were contacted by emails, using some references, and through telephonic contact. Data for the study was collected using an online survey on two points of time divided by the gap of 1 month to lessen the potential common method biases [58]. All the respondents were informed that the research was purely for academic purposes. Data was collected in two points of time. First point of time, data related to demographics of participants, responsible leadership and psychological ownership was collected online through spreading a survey link. At the second point of time, we asked the employees to give their responses related to OCBE and employee environmental commitment.

In six organizations approximately 750 employees were randomly selected, so a total of 750 survey links were distributed out of which 520 (69.33 percent) were received back completed in all sense and were used for data analysis. Out of these 520 respondents, 232 respondents (44.6 percent) were female, and 288 (55.4 percent) were male respondents. The age-wise distribution includes five age brackets. The first age bracket consists of age 20-25 and 71 respondents fall in this bracket. The second age bracket is 25 to 30 and a total 132 respondents fall in this age category. 240 respondents that are 46 percent fall in the third age group of 30-35. Similarly, the fourth age group has an age limit $35-40$, and a total 55 respondents fall in this age group that is 10.6 percent of total respondents. The lowest number i.e. 22 respondents falls in the highest age group of above 40 . The sample employees having work experience between 1-5 years are 30.2 percent, the highest employees having work experience between 5-10 years are 45.4 percent, and the remaining 24.4 percent have work experience above 10 years. In employees' education level distribution, 65.4 percent of respondents have a bachelor's degree while 23.8 percent of respondents have a master level degree. Supplementary information of the respondents is shown in below Table 1 .

\subsection{Measures}

The measure of the study is divided into three parts. In the first part, the overview of the study is given and the importance of the role of responses is discussed. The purpose of the study is clarified to the respondents and it is further informed that the research was purely for academic purposes. In the second part, demographics are asked i.e. gender, age, education, and work experience of the respondents. In the third and main part of the questioner, items related to variables of the study were asked. The respondents answered the questionnaire on a five-point Likert scale from 1 (strongly agree) to 5 (strongly disagree). The questioner was translated into the Chinese language to facilitate respondents.

\subsubsection{Responsible Leadership}

Responsible leadership measure was assessed by using five items scale developed by [두]. The questions include ("My direct supervisor demonstrates awareness for the relevant stakeholder claims", "My direct supervisor weighs different stakeholder claims before making a decision", "My direct supervisor considers the consequences of decisions for the affected stakeholders", "My direct supervisor involves the affected stakeholders in the decision-making process" and the last item is "My direct supervisor tries to achieve a consensus among the affected stakeholders"). The Cronbach's alpha was 0.82 for the above-mentioned items.

\subsubsection{Organizational citizenship behavior for the environment}


We used the 10 item scale of OCBE developed by Boiral \& Paillé [ㄹ5]. Sample items include but not limited to ("In my work, I weigh the consequences of my actions before doing something that could affect the environment", "I undertake environmental actions that contribute positively to the image of my organization" and "I spontaneously give my time to help my colleagues take the environment into account in everything they do at work"). The Cronbach's alpha of these items was 0.81 .

\subsubsection{Psychological Ownership}

We assessed psychological ownership by the scale developed by Pierce and colleagues [으]. Five items Likert scale was used, where 1 donated for "Strongly agree" and 5 donated for "Strongly disagree". The sample items include ("I feel that I belong in this organization", "For me, the organization is home", "I am totally comfortable being in this organization", "I feel that this organization's success is my success" and "I feel that being a member in this organization helps me realize my value"). The Cronbach's Alpha of these items was 0.83 .

\subsubsection{Employee Environmental Commitment}

The eight-item scale of employee environmental commitment was developed by [49], and we utilized the same. The Cronbach's alpha of this scale was 0.82. Sample items include ("The environmental concern of my company means a lot to me" and "I really care about the environmental concern of my company").

\section{Data analysis and results}

In this study, data were examined using SPSS 25 and AMOS. The bootstrapping technique in SPSS 25 was also used in this study. The existing study in OCBE Khan, et al. [61] has recommended AMOS because, of the large sample size and good statistical analysis. Test the convergent and discriminant validity of the scales, the measurement model was established, convergent validity aims to investigate whether the items measure a similar concept or not. That contains composite reliability and average variance extracted. According to Hair, et al. [62], the average variance extracted (AVE) exceed the value of 0.50 and composite reliability (CR) exceed the value of 0.70 are accepted. To test the hypotheses' structural model was established, coefficient values, confidence intervals, $\mathrm{P}$ values, and $t$-statistics were calculated.

\subsection{Results}

Table 1. Respondent's Demographic characteristics

\begin{tabular}{cccccc}
\hline & & Frequency & Percent & Valid Percent & $\begin{array}{c}\text { Cumulative } \\
\text { Percent }\end{array}$ \\
\hline Gender & Male & 288 & 55.4 & 55.4 & 55.4 \\
& Female & 232 & 44.6 & 44.6 & 100.0 \\
Age & $20-25$ & 71 & 13.7 & 13.7 & 13.7 \\
& $25-30$ & 132 & 25.4 & 25.4 & 39.0 \\
& $30-35$ & 240 & 46.2 & 46.2 & 85.2 \\
Education & $35-40$ & 55 & 10.6 & 10.6 & 95.8 \\
& Above 40 & 22 & 4.2 & 4.2 & 100.0 \\
& High School & 8 & 1.5 & 1.5 & 1.5 \\
& Senior High School & 30 & 5.8 & 5.8 & 7.3 \\
& Bachelor & 340 & 65.4 & 65.4 & 72.7 \\
& Master & 124 & 23.8 & 23.8 & 96.5 \\
Experience & Others & 18 & 3.5 & 3.5 & 100.0 \\
\hline
\end{tabular}




\begin{tabular}{ccccc}
\hline 1-5 years & 157 & 30.2 & 30.2 & 35.0 \\
5-10 years & 236 & 45.4 & 45.4 & 80.4 \\
10- 20 years & 85 & 16.3 & 16.3 & 96.7 \\
More than 20 Years & 17 & 3.3 & 3.3 & 100.0 \\
\hline
\end{tabular}

Table 2. Convergent validity

\begin{tabular}{|c|c|c|c|c|c|}
\hline Variable & Items & $\begin{array}{c}\text { Standardized } \\
\text { factor } \\
\text { Loadings }\end{array}$ & $\begin{array}{c}\text { Cronbach's } \\
\text { Alpha }\end{array}$ & $\begin{array}{l}\text { Composite } \\
\text { Reliability }\end{array}$ & $\begin{array}{c}\text { Average } \\
\text { Variance } \\
\text { Extracted (AVE) }\end{array}$ \\
\hline \multirow[t]{2}{*}{ Responsible leadership } & RL-1 & 0.850 & 0.905 & 0.928 & 0.722 \\
\hline & $\begin{array}{l}\text { RL-2 } \\
\text { RL-3 } \\
\text { RL-4 } \\
\text { RL-5 }\end{array}$ & $\begin{array}{l}0.851 \\
0.823 \\
0.863 \\
0.860\end{array}$ & & & \\
\hline \multirow[t]{2}{*}{ Psychological Ownership } & PO-1 & 0.831 & 0.884 & 0.915 & 0.684 \\
\hline & $\begin{array}{l}\text { PO-2 } \\
\text { PO-3 } \\
\text { PO-4 } \\
\text { PO-5 }\end{array}$ & $\begin{array}{l}0.804 \\
0.832 \\
0.848 \\
0.822\end{array}$ & & & \\
\hline \multirow[t]{2}{*}{$\begin{array}{c}\text { Employees } \\
\text { Environmental } \\
\text { commitment }\end{array}$} & EEC-1 & 0.773 & 0.926 & 0.938 & 0.656 \\
\hline & $\begin{array}{l}\text { EEC-2 } \\
\text { EEC-3 } \\
\text { EEC-4 } \\
\text { EEC-5 } \\
\text { EEC-6 } \\
\text { EEC-7 } \\
\text { EEC-8 }\end{array}$ & $\begin{array}{l}0.816 \\
0.836 \\
0.821 \\
0.820 \\
0.794 \\
0.807 \\
0.811\end{array}$ & & & \\
\hline Organizational & OCBE-1 & & & & \\
\hline \multirow[t]{10}{*}{$\begin{array}{l}\text { Citizenship Behavior for } \\
\text { the Environment }\end{array}$} & & 0.774 & 0.940 & 0.949 & 0.651 \\
\hline & OCBE-2 & 0.779 & & & \\
\hline & OCBE-3 & 0.811 & & & \\
\hline & OCBE-4 & 0.850 & & & \\
\hline & OCBE-5 & 0.783 & & & \\
\hline & OCBE-6 & 0.849 & & & \\
\hline & OCBE-7 & 0.798 & & & \\
\hline & OCBE-8 & 0.809 & & & \\
\hline & OCBE-9 & 0.817 & & & \\
\hline & OCBE-10 & 0.795 & & & \\
\hline
\end{tabular}


First of all, screening of data was carried out to find out the missing values, any abnormal response of outliers, the test of differences, and the technique of common method variance. The Famous Harman single factor test for common method bias was carried out to undertake the factor analysis (exploratory) by using SPSS 25. We consider all the variables (responsible leadership, OCBE, psychological ownership, and employee environmental commitment) for factor analysis. The highest covariance value was $36.40 \%$ (below $50 \%$ ) indicated that the common method bias problem does not exist.

Table 2 indicates each value of Cronbach's Alpha is greater than 0.80 , which indicates that the values of all factors are above 0.5 that are acceptable and composite reliability is higher than 0.80 [ $\underline{63}]$, thus the adequate reliability for each item is ensured. The content validity of the scale of study is ensured through a comprehensive review of the literature and feedback received from researchers. All the items of instrument were translated into the Chinese language to make them easily understandable for Chinese respondents and then all the items were translated back into the English language to ensure the validity of the contents. In confirmatory factor analysis, all the factors' loadings are higher than 0.50 that indicates the convergent validity [64]. That contains composite reliability and average variance extracted. According to [62], the average variance extracted (AVE) exceeds the value of 0.50 and composite reliability (CR) exceed the value of 0.70 are accepted.

Table 3. Model Fitness

\begin{tabular}{cccccccc}
\hline Model & $\mathrm{X}^{2}$ & $\mathrm{df}$ & $\mathrm{X}^{2} / \mathrm{df}$ & $\mathrm{CFI}$ & $\mathrm{TLI}$ & RMR & RMSEA \\
\hline Model 3.Three factor Model & 187.843 & 55 & 3.415 & 0.972 & 0.961 & 0.070 & 0.068 \\
Model 2.Two factor model & 595.583 & 129 & 4.617 & 0.935 & 0.923 & 0.069 & 0.083 \\
Model 1.One factor & 1723.945 & 330 & 5.224 & 0.896 & 0.881 & 0.084 & 0.090 \\
\hline
\end{tabular}

Note. ${ }^{* * *} \mathrm{p}<0.001 . \mathrm{N}=520, \mathrm{CFI}=$ comparative fit index; RMSEA= root-mean-square error of approximation; TLI= Tucker-Lewis index; Responsible leadership; Psychological Ownership; Employees environmental commitment; OCBE.

We used AMOS to assess the model fitness and hypothesized results. We built the model fitness around various statistical indices, such as $\chi 2$, CFI, TLI, and RMSEA following [62]. The CFI and TLI values within the range of $0.90-1.00$ are considered good fit indices, whereas RMSEA values less than 0.05 and between 0.06 and 0.08 are deemed good fit and acceptable, respectively. The results showed the following fit index values: $\chi 2,=187.843, \chi 2 / \mathrm{df}=3.415, \mathrm{CFI}=0.972 ; \mathrm{TLI}=0.961$; $\mathrm{RMSEA}=0.068$ which demonstrated that the fitness values are within the recommended ranges according to [62].

Table 4. Means, standard deviations, Matrix for study variables

\begin{tabular}{|c|c|c|c|c|c|c|c|c|c|c|}
\hline Variables & Means & S.D. & 1 & 2 & 3 & 4 & 5 & 6 & 7 & 8 \\
\hline 1-Gender & 1.45 & 0.498 & 1 & & & & & & & \\
\hline 2-Age & 2.66 & 0.982 & -.031 & 1 & & & & & & \\
\hline 3-Education & 3.22 & 0.670 & $.111^{*}$ & $.153^{* *}$ & 1 & & & & & \\
\hline 4-Experience & 2.83 & 0.873 & $-.088^{*}$ & $.815^{* *}$ & $.103^{*}$ & 1 & & & & \\
\hline $\begin{array}{l}\text { 5-Responsible } \\
\text { leadership }\end{array}$ & 2.47 & 1.02 & .057 & $-.243^{* *}$ & $.125^{* *}$ & $-.217^{* *}$ & 1 & & & \\
\hline
\end{tabular}




\begin{tabular}{|c|c|c|c|c|c|c|c|c|c|c|}
\hline $\begin{array}{c}\text { 6-Psychological } \\
\text { ownership }\end{array}$ & 2.15 & 0.88 & .036 & -.060 & $-.157^{* *}$ & -.086 & $.331^{* *}$ & 1 & & \\
\hline $\begin{array}{l}\text { 7-Employees } \\
\text { environmental } \\
\text { Commitment }\end{array}$ & 2.16 & 0.878 & .071 & -.034 & $-.105^{*}$ & -.046 & $.328^{* *}$ & $.885^{* *}$ & 1 & \\
\hline 8-OCBE & 2.55 & 0.946 & .050 & $-.225^{* *}$ & $.102^{*}$ & $-.215^{* *}$ & $.891^{* *}$ & $.424^{* *}$ & $.452^{* *}$ & 1 \\
\hline
\end{tabular}

Notes: $\mathrm{N}=520 .{ }^{*} \mathrm{p}<0.05 ;{ }^{* *} \mathrm{p}<0.01 ; \mathrm{SE}=$ Standard error; $\mathrm{SD}=$ standard deviation.

The above table indicated means, standard deviation, and correlation among variables, the results reveal that personal correlation among variables were positive and significant at the 0.01 level. Therefore other demographics variables such as age, gender, education, the organization indicated mean value with standard deviation and standard error, furthermore other constructs such responsible leadership, psychological ownership, employees environmental commitment and organizational citizenship behavior for the environmental indicated significant and positive correlations, below tables shows the means values with standard deviation and standard error, all values are significantly correlated such as $(\mathrm{r}=0.331, \mathrm{p}<0.01)$ these results shows about responsible leadership and psychological ownership and more about employees environmental commitment and responsible leadership indicated $(\mathrm{r}=0.328, \mathrm{p}<0.01)$. Employees' environmental commitment and psychological ownership show a strange correlation $(\mathrm{r}=0.885, \mathrm{p}<0.01)$. The OCBE shows positive correlations with all other constructs.

Table 5. Hypothesis Testing

\begin{tabular}{|c|c|c|c|c|c|c|}
\hline Hypotheses & Coefficient & S.D. & T-value & P-value & LLCI & ULCI \\
\hline RL > OCBE & 0.298 & 0.056 & 5.26 & 0.000 & 0.187 & 0.409 \\
\hline $\mathrm{RL}>\mathrm{PO}$ & 0.284 & 0.036 & 7.974 & 0.000 & 0.214 & 0.354 \\
\hline $\mathrm{PO}>\mathrm{OCBE}$ & 0.156 & 0.022 & 0.019 & 0.000 & 0.114 & 0.199 \\
\hline $\mathrm{RL}>\mathrm{PO}>\mathrm{OCBE}$ & 0.238 & 0.017 & 4.705 & 0.000 & 0.152 & 0.325 \\
\hline $\mathrm{RL}^{*} \mathrm{EEC}>\mathrm{PO}$ & 0.063 & 0.023 & 2.799 & 0.005 & 0.107 & 0.019 \\
\hline $\mathrm{RL}^{*} \mathrm{EEC}>\mathrm{OCBE}$ & 0.065 & 0.021 & 2.949 & 0.003 & 0.022 & 0.108 \\
\hline
\end{tabular}

Notes: ULCI= Upper level confidence interval; LLCI = Lower level confidence interval; SD= standard deviation; ${ }^{* *}$ p-value < 0.01; ${ }^{*}$ p-value < 0.05; RL= Responsible leadership; PO= Psychological Ownership; EEC; Employees environmental commitment; OCBE; Organizational citizenship behavior for the environmental.

Table 5 represent data of hypothesis testing shows that there is a significant and positive relationship exist between responsible leadership and OCBE $(\beta=0.298 ; \mathrm{P}<0.05)$ that provide support for our hypothesis H1, and also shows that there is a significant and positive relationship exist 
between responsible leadership and psychological ownership $(\beta=0.284 ; \mathrm{P}<0.05)$ that also support for our hypothesis H2. Furthermore, it has been indicated that psychological ownership has a significant positive influence on OCBE and results show that $(\beta=0.156 ; \mathrm{P}<0.05)$ psychological ownership changes organizational citizenship behavior to this extent. Therefore, these hypotheses $\mathrm{H} 1$ and $\mathrm{H} 2$, and also $\mathrm{H} 3$ are accepted in this study empirically, intensify the significant relationship among responsible leadership, psychological ownership, and OCBE. There is also a significant mediating effect of psychological ownership on the association of responsible leadership and OCBE, as the table indicated $(\beta=0.238 ; \mathrm{P}<0.05)$ and provides support for mediating relationship and accepted H4. Furthermore previously in the literature, we anticipated that employees environment commitment would moderate the relationship between responsible leadership and psychological ownership, additional supporting the moderation analysis, the strength of indirect value (mediation) is likely to rely on the value of moderation (i.e. psychological ownership) which is known as conditional indirect effects or moderated mediation [65]. Overall results show partial mediation. Tables 6 and 7 exhibit the direct and indirect effect of responsible leadership on OCBE and it indicated 0.298 effect and indirect effect indicated 0.238 .

Table 6. Direct Effect

\begin{tabular}{ccccccc}
\hline Direct Effect & Effect & S.D. & T-value & P-value & LLCI & ULCI \\
\hline & 0.298 & 0.056 & 5.26 & 0.000 & 0.187 & 0.409 \\
\hline
\end{tabular}

Notes: $\mathrm{SD}=$ Standard deviation; ULCI= Upper level confidence interval; LLCI = Lower level confidence interval.

Table 7. Indirect Effect

\begin{tabular}{ccccccc}
\hline Indirect Effect & Effect & S.D. & T-value & P-value & LLCI & ULCI \\
\hline & 0.238 & 0.017 & 4.705 & 0.000 & 0.152 & 0.325 \\
\hline
\end{tabular}

Notes: $\mathrm{SD}=$ Standard deviation; ULCI= Upper level confidence interval; LLCI = Lower level confidence interval.

Table 8, shows the values of standard error, and the bootstrap confidence interval of moderation conditional indirect effect of employee's environmental commitment respectively low medium and the high level of employees environmentally commitment, the conditional indirect effect of employee's environmental commitment significantly stronger and higher at the level of (0.1146) and significantly less strength at the lower level of (0.0177) therefore H5 is accepted. Table 9 shows the conditional moderation effect of employees' environmental commitment between responsible leadership and OCBE the higher level of value is (0.0032) and the lower is (0.005) so here our H6 is accepted.

Table 8. Results of the Indirect conditional effect (Moderation effect of EEC between RL and PO)

\begin{tabular}{ccccc}
\hline $\begin{array}{c}\text { Moderator } \\
\text { Value }\end{array}$ & Effect & Bootstrap SE & Bootstrap LLCI & Bootstrap ULCI \\
\hline 1.5000 & 0.0017 & 0.0219 & -0.0448 & 0.0414 \\
1.7500 & 0.0177 & 0.0194 & 0.0204 & 0.0558 \\
3.0000 & 0.1146 & 0.0291 & 0.0574 & 0.1718 \\
\hline
\end{tabular}

Notes: SE= Standard error; ULCI= Upper level confidence interval; LLCI= Lower level confidence interval; Number of bootstrap samples $=520$; Level of Confidence $=95 \%$; RL= Responsible leadership; PO= Psychological ownership. 
Table 9. Results of the conditional indirect effect (Moderation effect of EEC between RL and OCBE)

\begin{tabular}{ccccc}
\hline Moderator Value & Effect & Bootstrap SE & Bootstrap LLCI & Bootstrap ULCI \\
\hline 1.5000 & 0.0000 & 0.0010 & 0.0023 & 0.0022 \\
1.7500 & 0.0005 & 0.0013 & 0.0039 & 0.0017 \\
3.0000 & 0.0032 & 0.0064 & 0.0178 & 0.0084 \\
\hline
\end{tabular}

Notes: SE= Standard error; ULCI= Upper level confidence interval; LLCI= Lower level confidence interval; Number of bootstrap samples $=520$; Level of Confidence $=95 \%$; $R L=$ Responsible leadership; OCBE $=$ Organizational citizenship behavior for the environment.

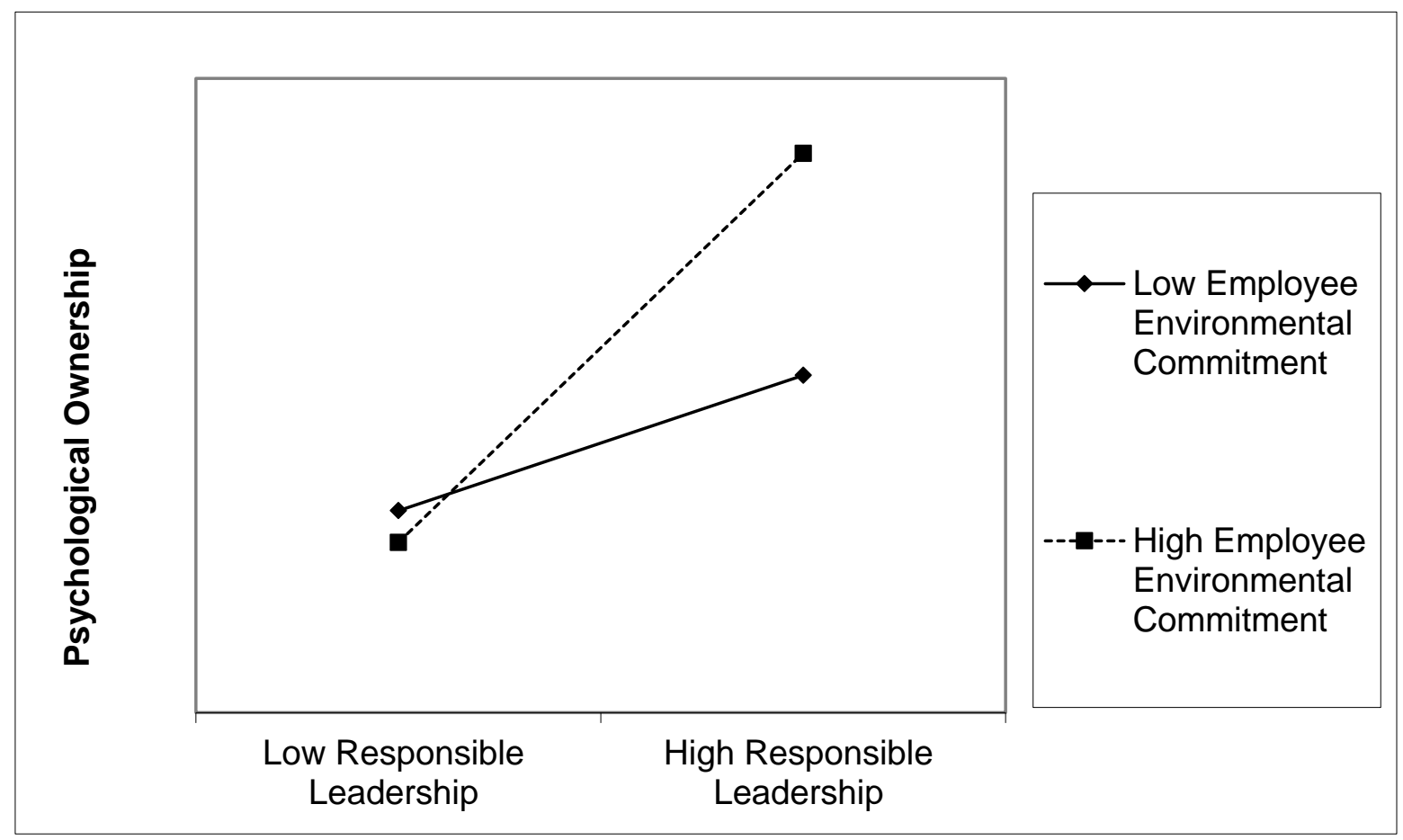

Figure 2. Interaction Chart

The above interaction, chart shows the moderation effect it's shows two arrows are interacting with each other on point so it indicates that there is moderation exists between responsible leadership and psychological ownership.

\section{Discussion}

According to Voegtlin, et al. [21], Responsible leadership is the most emerging and compensated leadership to enhance the environmental reputation and maintain sustainable development of the organization and society. The stakeholder theory elaborates responsible leadership, corporate social responsibility (CSR), and leadership ethics. Past studies of Han, et al. [1] indicated that responsible leadership positively impacts OCBE. In this study, by performing path analysis we attempted to answer the role of responsible leadership with OCBE. How does responsible leadership support OCBE on the basis of social learning theory? We based on mediator and moderator developed a conceptual model that included psychological ownership and employee's environmental commitment. The results indicated that responsible leadership behavior provides support for OCBE. In our research environment, specific responsible leadership was found to foster employees through 
psychological ownership mediation. Additionally, employees' environmental commitment plays a moderating role to intensify the effect.

This study adds psychological ownership to differentiate these two mechanisms with employee's environmental commitment as a control moderator. The result showed that psychological ownership mediates the relationship between responsible leadership and OCBE. In practice, the results indicated some new suggestions on how to encourage employees to actively engage in OCBE within the organization. Furthermore, this study indicated a partial mediation in the table of mediation, the results showed a significant linkage of mediator psychological ownership playing a mediator role between responsible leadership and OCBE. These findings are in line with previous studies of $[1,13]$, who argued that responsible leadership is essential for promoting sustainabilityrelated behavior among employees. This is why because responsible leaders can lead existing employees to strive for sustainable priorities and values, particularly development. In return, employees engage in sustainable practices, i.e. pro-environmental behaviors. As compared to the traditional leadership behaviors and leader-follower perspective, responsible leadership is more helpful in improving sustainable personal behaviors. Furthermore, employee environmental commitment positively moderated the mechanism linking between responsible leadership and psychological ownership such that this indirect influence was significantly positive. Our study argued a moderating effect that influences the relationship between responsible leadership and psychological ownership. Furthermore, employees' environmental commitment plays moderating effects to intensify the relationship between responsible leadership and OCBE.

\section{Conclusions}

According to Voegtlin, et al. [21], Responsible leadership is one of the most emerging and compensated leadership to enhance the repute of an organization and maintain sustainable development of the organization and society. OCBE describes the employee's behavior related to environmental protection that is not governed by any organisation's formal reward system. Principally, it is employees' optional behavior directed towards environmental protection and epitomizes an operative supplement for the peoples' environmental safeguarding behaviour and the green growth approaches of the organizations (Daily et al., 2009).

In this research, we endeavor to investigate the association between responsible leadership and OCBE in the mechanism of psychological ownership and employee environmental commitment. The sample used for data analysis of this study consist of 520 employees from Chinese organizations. For data analysis the SPSS 25 and AMOS used and drew the following conclusions; Responsible leadership positively and significantly affects the OCBE after controlling age, gender, work experience, and education. Psychological ownership performed a mediating role in the relationship of responsible leadership and OCBE, and employee environmental commitment plays a moderating role between responsible leadership and psychological ownership, and responsible leadership and OCBE.

This study contributed theoretically to social learning and social exchange theories. The social learning theory strives for the compound behavior of people that are primarily acquired through direct and indirect observing and imitating the behavior of activists or objects (Bandura, 1971). In the study of Maak and Pless [19], responsible leadership is described as internal and external stakeholders protector with a varied range of associates with the enterprise and natural environment. We investigate and enrich the literature by examining the association between employee environmental protection behavior and responsible leadership i.e. OCBE. We studied and proved that responsible leadership develops a sense of responsibility and inspires employees to encompass environmental protection behavior. This research also emphasises the responsible leadership effect on the employees' behaviour and attitudes through employees' sense of psychological ownership for the institutions and employee environmental commitment for environmental protection. 


\subsection{Management and policy implications}

Depending on the findings of the current study, we draw the following management and policy implications. First, the role of responsible leadership in the growth of the organization should be highlighted. In an organizational setting, the managers' sense of CSR and environmental-related ethics affect the employees' practices and attitudes. So, the manager's responsible leadership level should be improved. The manager's collaboration with employees should be established that will stimulate employee workplace environmental protection attitudes and practices and their efforts for organizational sustainable development. So the organizations should hire and develop such leaders who demonstrate the ethics and characteristics of responsible leadership. These ethics and values should be embedded in training and leadership development programs to support responsible leadership behaviour. Furthermore, the organizations encourage the employee's pro-environmental behavior by endorsing environmental-related attitudes and practices like reducing carbon emissions, saving energy, and reusing resources.

Second, the employee psychological ownership affects employees' motivation to involve in environmental protection behavior. To increase the level of OCBE in the organization, it is essential to stimulate their sense of psychological ownership for the organization. In return, the employee will exhibit environmental protection behavior. Psychological ownership gives employees a sense of ownership in the organization, so they feel more attached to the organization, strive for its sustainable development, and in this way show the environmental protection behavior. Therefore, such training programs should be implemented to enhance the employees' sense of psychological ownership for the organization and increase skills to participate in environmental protection activities.

\subsection{Research Limitations and Future Directions}

There are also a few limitations associated with this study to be deliberated. First of all, the instrument used to measure responsible leadership is derivative from scales developed for the western perspective. Scales have good validity and reliability, but the theoretical association of responsible leadership and its endorsement for diverse cultures particularly the eastern perspective, including China, needs further exploration. Second, although use of the time-lagged data reduces the chances of common method bias, it prevents any causative inferences. It is recommended for upcoming research to use longitudinal study designs to generate casual relationships. Third, in this study, psychological ownership and employee environmental commitment were used as mediating and moderation agent simultaneously between responsible leadership and OCBE; other dominant variables such as environmental awareness [6], the role of HR for developing green culture and climate [67] should be further investigated in upcoming research. Fourth, in upcoming studies, the Chinese prospective should be further enlarged and include other eastern countries to examine and enlarge the eastern stand on environmental issues. Fifth, data for leadership prospective was evaluated by employee and not by the leaders itself. In future studies we call for leaders' selfevaluation for leadership traits and its impact on employees OCBE.

Author Contributions: Conceptualization, A.A. and B.; methodology, I.U.; software, S.M.; validation, A.A., B., and H.M.A.; formal analysis, I.U.; investigation, B., A.A., C.Y.; resources, H.M.A.; data curation, B., and A.A.; writing-original draft preparation, S.M, A.A., B., and H.M.A.; writing-review and editing, N S.M, A.A., B., and H.M.A.; visualization, I.U.; supervision, C.Y.; project administration, A.A.; funding acquisition, C.Y. All authors have read and agreed to the published version of the manuscript.

Conflicts of Interest: The authors declare no conflict of interest.

\section{References}

1. Han, Z.; Wang, Q.; Yan, X., How Responsible Leadership Motivates Employees to Engage in Organizational Citizenship Behavior for the Environment: A Double-Mediation Model. Sustainability 2019, 11, (3), 605 . 
2. Bansal, P.; Song, H.-C., Similar but not the same: Differentiating corporate sustainability from corporate responsibility. Academy of Management Annals 2017, 11, (1), 105-149.

3. Galpin, T.; Whittington, J. L., Sustainability leadership: From strategy to results. Journal of Business Strategy 2012.

4. Felin, T.; Foss, N. J.; Ployhart, R. E., The microfoundations movement in strategy and organization theory. The Academy of Management Annals 2015, 9, (1), 575-632.

5. Daily, B. F.; Bishop, J. W.; Govindarajulu, N., A conceptual model for organizational citizenship behavior directed toward the environment. Business $\mathcal{E}$ Society 2009, 48, (2), 243-256.

6. Ramus, C. A.; Steger, U., The roles of supervisory support behaviors and environmental policy in employee "ecoinitiatives" at leading-edge European companies. Academy of Management journal 2000, $43,(4), 605-626$.

7. Zhang, J.; Chen, Y.; Liu, J. In Ethical leadership and OCBE: The influence of prosocial motivation and self accountability, Academy of Management Proceedings, 2016; Academy of Management Briarcliff Manor, NY 10510: 2016; p 15588.

8. Temminck, E.; Mearns, K.; Fruhen, L., Motivating employees towards sustainable behaviour. Business Strategy and the Environment 2015, 24, (6), 402-412.

9. Lamm, E.; Tosti-Kharas, J.; King, C. E., Empowering employee sustainability: Perceived organizational support toward the environment. Journal of Business Ethics 2015, 128, (1), 207-220.

10. Han, Z.; Wang, Q.; Yan, X., How responsible leadership predicts organizational citizenship behavior for the environment in China. Leadership \& Organization Development Journal 2019.

11. Priyankara, H. P. R.; Luo, F.; Saeed, A.; Nubuor, S. A.; Jayasuriya, M. P. F., How does leader's support for environment promote organizational citizenship behaviour for environment? A multi-theory perspective. Sustainability 2018, 10, (1), 271.

12. Li, Z.; Xue, J.; Li, R.; Chen, H.; Wang, T., Environmentally Specific Transformational Leadership and Employee's Pro-environmental Behavior: The Mediating Roles of Environmental Passion and Autonomous Motivation. Frontiers in psychology 2020, 11.

13. Zhao, H.; Zhou, Q., Exploring the impact of responsible leadership on organizational citizenship behavior for the environment: A leadership identity perspective. Sustainability 2019, 11, (4), 944.

14. Zhao, H.; Zhou, Q., Socially responsible human resource management and hotel employee organizational citizenship behavior for the environment: A social cognitive perspective. International Journal of Hospitality Management 2020, 102749.

15. Jiang, M.; Li, M., Linking empowering leadership and organizational citizenship behavior toward environment: the role of psychological ownership and future time perspective. Frontiers in psychology 2019, 10, 2612.

16. Mi, L.; Gan, X.; Xu, T.; Long, R.; Qiao, L.; Zhu, H., A new perspective to promote organizational citizenship behaviour for the environment: The role of transformational leadership. Journal of Cleaner Production 2019, 239, 118002.

17. Pham, N. T.; Thanh, T. V.; Tučková, Z.; Thuy, V. T. N., The role of green human resource management in driving hotel's environmental performance: Interaction and mediation analysis. International Journal of Hospitality Management 2020, 88, 102392.

18. Tuan, L., Catalyzing employee OCBE in tour companies: the role of environmentally specific charismatic leadership and organizational justice for pro-environmental behaviors. J. Hosp. Tour. Res 2019, 43, 682-711. 
19. Maak, T.; Pless, N. M., Responsible leadership in a stakeholder society-a relational perspective. Journal of Business Ethics 2006, 66, (1), 99-115.

20. Miska, C.; Hilbe, C.; Mayer, S., Reconciling different views on responsible leadership: A rationalitybased approach. Journal of Business Ethics 2014, 125, (2), 349-360.

21. Voegtlin, C.; Patzer, M.; Scherer, A. G., Responsible leadership in global business: A new approach to leadership and its multi-level outcomes. Journal of Business Ethics 2012, 105, (1), 1-16.

22. Lawrence, P. R.; Pirson, M., Economistic and humanistic narratives of leadership in the age of globality: Toward a renewed Darwinian theory of leadership. Journal of Business Ethics 2015, 128, (2), 383-394.

23. Pless, N. M.; Maak, T.; Stahl, G. K., Developing responsible global leaders through international servicelearning programs: The Ulysses experience. Academy of Management Learning E Education 2011, 10, (2), 237-260.

24. Voegtlin, C., What does it mean to be responsible? Addressing the missing responsibility dimension in ethical leadership research. Leadership 2016, 12, (5), 581-608.

25. Boiral, O.; Paillé, P., Organizational citizenship behaviour for the environment: Measurement and validation. Journal of Business Ethics 2012, 109, (4), 431-445.

26. Alt, E.; Spitzeck, H., Improving environmental performance through unit-level organizational citizenship behaviors for the environment: A capability perspective. Journal of environmental management 2016, 182, 48-58.

27. Paillé, P.; Chen, Y.; Boiral, O.; Jin, J., The impact of human resource management on environmental performance: An employee-level study. Journal of Business Ethics 2014, 121, (3), 451-466.

28. Zientara, P.; Zamojska, A., Green organizational climates and employee pro-environmental behaviour in the hotel industry. Journal of Sustainable Tourism 2018, 26, (7), 1142-1159.

29. Paillé, P.; Raineri, N.; Boiral, O., Environmental behavior on and off the job: A configurational approach. Journal of Business Ethics 2017, 1-16.

30. De Groot, J. I.; Steg, L., Relationships between value orientations, self-determined motivational types and pro-environmental behavioural intentions. Journal of Environmental Psychology 2010, 30, (4), 368-378.

31. Bandura, A., Social foundations of thought and action. Englewood Cliffs, NJ 1986, 1986.

32. Stahl, G. K.; Sully de Luque, M., Antecedents of responsible leader behavior: A research synthesis, conceptual framework, and agenda for future research. Academy of Management Perspectives 2014, 28, (3), 235-254.

33. Pierce, J. L.; Kostova, T.; Dirks, K. T., Toward a theory of psychological ownership in organizations. Academy of management review 2001, 26, (2), 298-310.

34. Avey, J. B.; Avolio, B. J.; Crossley, C. D.; Luthans, F., Psychological ownership: Theoretical extensions, measurement and relation to work outcomes. Journal of Organizational Behavior: The International Journal of Industrial, Occupational and Organizational Psychology and Behavior 2009, 30, (2), 173-191.

35. Pierce, J. L.; Kostova, T.; Dirks, K. T., The state of psychological ownership: Integrating and extending a century of research. Review of general psychology 2003, 7, (1), 84-107.

36. Van Dyne, L.; Pierce, J. L., Psychological ownership and feelings of possession: Three field studies predicting employee attitudes and organizational citizenship behavior. Journal of Organizational Behavior: The International Journal of Industrial, Occupational and Organizational Psychology and Behavior 2004, 25, (4), 439-459.

37. Bernhard, F.; O'Driscoll, M. P., Psychological ownership in small family-owned businesses: Leadership style and nonfamily-employees' work attitudes and behaviors. Group E Organization Management 2011, 36, (3), 345-384. 
38. Kim, M.; Beehr, T. A., Self-efficacy and psychological ownership mediate the effects of empowering leadership on both good and bad employee behaviors. Journal of Leadership E Organizational Studies 2017, 24, (4), 466-478.

39. O'driscoll, M. P.; Pierce, J. L.; Coghlan, A.-M., The psychology of ownership: Work environment structure, organizational commitment, and citizenship behaviors. Group E Organization Management 2006, 31, (3), 388-416.

40. Wang, L.; Law, K. S.; Zhang, M. J.; Li, Y. N.; Liang, Y., It's mine! Psychological ownership of one's job explains positive and negative workplace outcomes of job engagement. Journal of Applied Psychology 2019, 104, (2), 229.

41. Lawler, E. J.; Thye, S. R.; Yoon, J., Social commitments in a depersonalized world. Russell Sage Foundation: 2009.

42. Meyer, J. P.; Herscovitch, L., Commitment in the workplace: Toward a general model. Human resource management review 2001, 11, (3), 299-326.

43. Cohen, A., Multiple commitments in the workplace: An integrative approach. Psychology Press: 2003.

44. Cantor, D. E.; Morrow, P. C.; Montabon, F., Engagement in environmental behaviors among supply chain management employees: An organizational support theoretical perspective. Journal of Supply Chain Management 2012, 48, (3), 33-51.

45. Keogh, P. D.; Polonsky, M. J., Environmental commitment: a basis for environmental entrepreneurship? Journal of organizational change management 1998, 11, (1), 38-49.

46. Perez, O.; Amichai-Hamburger, Y.; Shterental, T., The dynamic of corporate self-regulation: ISO 14001, environmental commitment, and organizational citizenship behavior. Law E Society Review 2009, 43, (3), 593-630.

47. Bingham, J. B.; Mitchell, B. W.; Bishop, D. G.; Allen, N. J., Working for a higher purpose: A theoretical framework for commitment to organization-sponsored causes. Human resource management review 2013, 23, (2), 174-189.

48. Meyer, J. P.; Parfyonova, N. M., Normative commitment in the workplace: A theoretical analysis and re-conceptualization. Human resource management review 2010, 20, (4), 283-294.

49. Raineri, N.; Paillé, P., Linking corporate policy and supervisory support with environmental citizenship behaviors: The role of employee environmental beliefs and commitment. Journal of Business Ethics 2016, 137, (1), 129-148.

50. Daily, B. F.; Huang, S. c., Achieving sustainability through attention to human resource factors in environmental management. International Journal of operations $\mathcal{E}$ production management 2001.

51. Morgan, R. M.; Hunt, S. D., The commitment-trust theory of relationship marketing. Journal of marketing 1994, 58, (3), 20-38.

52. Srivastava, A. P.; Dhar, R. L., Impact of leader member exchange, human resource management practices and psychological empowerment on extra role performances. International Journal of Productivity and Performance Management 2016.

53. Erdogan, B.; Bauer, T. N.; Taylor, S., Management commitment to the ecological environment and employees: Implications for employee attitudes and citizenship behaviors. Human Relations 2015, 68, (11), 1669-1691.

54. Montabon, F.; Morrow, P. C.; Cantor, D. E., Promoting environmental citizenship behaviour. International Journal of Integrated Supply Management 2016, 10, (1), 63-88.

55. Robertson, J. L.; Barling, J., Greening organizations through leaders' influence on employees' proenvironmental behaviors. Journal of organizational behavior 2013, 34, (2), 176-194. 
56. Bagozzi, R. P., The self-regulation of attitudes, intentions, and behavior. Social psychology quarterly 1992, 178-204.

57. Brislin, R. W., Translation and content analysis of oral and written materials. Methodology 1980, 389-444.

58. Podsakoff, P. M.; MacKenzie, S. B.; Lee, J.-Y.; Podsakoff, N. P., Common method biases in behavioral research: a critical review of the literature and recommended remedies. Journal of Applied Psychology 2003, 88, (5), 879.

59. Voegtlin, C., Development of a scale measuring discursive responsible leadership. In Responsible leadership, Springer: 2011; pp 57-73.

60. Pierce, J. L.; Rubenfeld, S. A.; Morgan, S., Employee ownership: A conceptual model of process and effects. Academy of management review 1991, 16, (1), 121-144.

61. Khan, M. A. S.; Ali, M.; Usman, M.; Saleem, S.; Jianguo, D., Interrelationships between ethical leadership, green psychological climate, and organizational environmental citizenship behavior: the moderating role of gender. Frontiers in psychology 2019, 10, 1977.

62. Hair, J. F.; Anderson, R. E.; Tatham, R. L.; Black, W. C., Multivariate Data Analysis, Prentice Hall, Upper Saddle River, NJ. 2010.

63. Fornell, C.; Larcker, D. F., Structural equation models with unobservable variables and measurement error: Algebra and statistics. In Sage Publications Sage CA: Los Angeles, CA: 1981.

64. Chau, P. Y., Reexamining a model for evaluating information center success using a structural equation modeling approach. Decision Sciences 1997, 28, (2), 309-334.

65. Hayes, A. F.; Rockwood, N. J., Conditional process analysis: Concepts, computation, and advances in the modeling of the contingencies of mechanisms. American Behavioral Scientist 2020, 64, (1), 19-54.

66. Afsar, B.; Cheema, S.; Javed, F., Activating employee's pro-environmental behaviors: The role of CSR, organizational identification, and environmentally specific servant leadership. Corporate Social Responsibility and Environmental Management 2018, 25, (5), 904-911.

67. Luu, T. T., Green human resource practices and organizational citizenship behavior for the environment: the roles of collective green crafting and environmentally specific servant leadership. Journal of Sustainable Tourism 2019, 27, (8), 1167-1196. 